\title{
Anticachexia Agent MT-102
}

National Cancer Institute

\section{Source}

National Cancer Institute. Anticachexia Agent MT-102. NCI Thesaurus. Code C95700.

A small molecule with potential anticachexia activity. The anticachexia agent MT-102

may increase protein synthesis and decrease muscle protein breakdown. This may result in improved body weight, muscle mass and may improve weakness and fatigue associated with cancer-related cachexia. 